\title{
ПАРЦЕЛЬОВАНІ СКЛАДНОПІДРЯДНІ РЕЧЕННЯ З ПІДРЯДНИМ КОМПОНЕНТОМ ПРИЧИНИ ЯК ОДИНИЦЯ ХУДОЖНЬОГО СИНТАКСИСУ В УКРАЇНСЬКІЙ ПРОЗІ КІНЦЯ ХХ - ПОЧАТКУ ХХІ СТОЛІТТЯ
}

Волобуєва О. О. Парцельовані складнопідрядні речення з підрядним компонентом причини як одиниця художнього синтаксису в українській прозі кінця XX - початку XXI століття.

У пропонованій статті автор робить спробу визначити особливості реалізації парцельованих складнопідрядних речень із підрядним компонентом причини, зокрема виділити їхні різновиди за ступенем зв'язаності базової структури і парцелята й за ступенем їх смислової зв'язаності, а також окреслює їхні функції в художньому творі.

Ключові слова: парцеляція, складнопідрядне речення 3 підрядним компонентом причини, базова структура, парцелят, основне висловлювання, комунікативний варіант.

Волобуева Е. А. Парцеллированные сложноподчиненные предложения с придаточным компонентом причины как единица художественного синтаксиса в украинской прозе конца XX - начала XXI века.

В предлагаемой статье автор определяет особенности реализации парцеллированных сложноподчиненных предложений с придаточным компонентом причины, выделяет их типы по степени связанности базовой структуры и парцеллята и по степени их смысловой спаянности, а также характеризует их функции в художественном произведении.

Ключевые слова: парцелляция, сложноподчиненное предложение с придаточным компонентом причины, базовая структура, парцеллят, основное высказывание, коммуникативный вариант.

Volobuyeva O. O. Parceled compound sentences with cause-subordinate clause as a unit of syntax in Ukrainian prose of the late $20^{\text {th }}$ - early $21^{\text {st }}$ century.

In this article the author defines the characteristics of the parceled compound sentences with cause-subordinate clause, highlights their types according to the degree of connectedness of basic structure and parceling and their degrees of semantic cohesion. The author also characterizes their functions in a literary work.

Key words: parceling, compound sentences with cause-subordinate clause, the basic structure, parcelate, basic saying, communicative option.

Питання парцеляції складних речень неодноразово викликало науковий інтерес в українських і російських синтаксистів, зокрема М. А. Авласевич, Н. С. Валгіної, Ю. В. Ванникова, Л. М. Жданович, О. С. Звєревої, Р. О. Зелепукіна, Н. А. Конопленко, Л. І. Конюхової, С. М. Марич, В. В. Орєхова, Г. Н. Рибакової, І. А. Ричкової, Ю. Л. Старовойта, Л. І. Ступакової, Л. С. Суровенкової, Т. В. Шевченко, В.А. Шитова. Дослідники зверталися до питань структурної й семантичної організації парцельованих складних конструкцій, аналізували особливості зв'язку між їхніми частинами, визначали їхні 
основні функції як граматичної, стилістичної й комунікативної одиниці. Незважаючи на значну кількість праць у цьому напрямі, в українській синтаксичній науці дотепер детально не схарактеризовані й не описані парцельовані складнопідрядні речення з підрядним компонентом причини, що й пояснює необхідність такого дослідження, підтверджує актуальність порушеної проблеми. У зв'язку $з$ цим уважаємо, що складнопідрядні речення, у яких підрядний компонент причини виступає парцелятом до базової частини складного речення, заслуговують на окремий розгляд.

Мета розвідки - визначити особливості реалізації парцельованих складнопідрядних речень із підрядним компонентом причини як одиниці художнього синтаксису в українській прозі кінця XX - початку ХХІ століття. Для досягнення поставленої мети необхідно виконати такі завдання: визначити типи парцельованих підрядних компонентів причини за ознакою ступеня зв’язаності цієї конструкції з попереднім контекстом та їх різновиди за ступенем смислової зв’язаності парцелята з базовою структурою; з'ясувати потенціал аналізованих синтаксичних конструкцій як одиниць експресивного й комунікативного синтаксису, окреслити їхні функції в художньому творі.

Задля одержання найбільш об’єктивних даних фактичний матеріал для дослідження дібрано з різних за жанрово-стильовими ознаками прозових творів, написаних в окреслений період розвитку української літератури: повісті Насті Байдаченко «Танок смерті», «Перший гріх Ізабели», Ірен Роздобудько «Лікарняна повість», «Все, що я хотіла сьогодні», романи С. Грицюка «Карпатський звіринець Паміра К.», В. Даниленка «Газелі бідного Ремзі», Люко Дашвар «Мати все», Оксани Забужко «Музей покинутих секретів», I. Корсака «Діти Яфета», «Отаман Чайка», Л. Костенко «Записки українського самашедшего», М. Матіос «Майже ніколи не навпаки», «Нація», «Солодка Даруся», Ірен Роздобудько «Я знаю, що ти знаєш, що я знаю», В. Шкляра «Чорний ворон».

Результати аналізу фактичного матеріалу засвідчили, що в українській художній прозі кінця XX - початку XXI століття за ознакою ступеня зв'язаності парцелята з попереднім контекстом уживаються (за визначенням Л. І. Ступакової [14, с. 99-100]):

- конструкції з обов'язковою опорою на одне зі слів базової структури (Папські посланцуі, щзо їхали через Лектур до Францї, мовчали, низько опустивии голови. Бо ж $і$ вони були лише чоловіками, $і$ в них тілесне бажання волало, заглушаючи доводи розуму чи бодай обачності (Настя Байдаченко) або на препозиційне основне висловлення загалом (- Тобі не повірять. Бо я священик, а ти - грішна жінка (Настя Байдаченко); Cтасе, не змушуй мене робити те, чого хочеш ти. Бо тоді я не зможу тебе любити (Люко Дашвар);

- конструкції з опорою на широкий контекст, який, крім препозиційної базової структури, містить інші речення, тобто 3 опорою на сукупність () О. О. Волобуєва, 2013. 
кількох попередніх речень і лише 3 останнім із них без участі інших співвідноситися не може: Я думаю, пора нам покопатися в тому, як саме вона загинула. За яких обставин. Бо ту відписку емгебешну, щуо у вас дома з $n$ 'ятдесят четвертого зберігається, у фільм втуляти просто срамотиння було б... (О. Забужко); - А ти думаєш, з якого дива матінка твоя три місяиі б'ється головою об стіну. А стіна - стоӥть! Бо молюся (Люко Дашвар).

3-поміж речень, що ілюструють засвідчені різновиди, також спостерігаються конструкції з абзацною парцеляцією:

а) Та поволі пам'ять вертає до неї.

Бо на горищуі монотонно икребе мима, а друга котить горіхи (М. Матіос); Я одразу ж хотіла встати $i$ піти. Адже ніколи не розмовляю із незнайомиями (Ірен Роздобудько);

б) Манія величі-цее хвороба.

Комплекс меншовартості - теж хвороба. Тільки ще гірша. Бо від манї величі станеш іспанським королем, як Поприщзін у Гоголя. А від комплексу меншовартості відчуєш себе комахою і побіжиш по стіні, як Грегор у Кафки (Л. Костенко); А з життя нема чого робити! Воно просто є. На нього можна хіба щзо скаржитись. Адже воно знецінене за рахунок циінного майна (Ірен Роздобудько).

За ступенем смислової зв'язаності парцелята зі значенням причини і базової структури (за визначенням Н. С. Валгіної [2, с. 283]) виділяються такі, що:

1) уточнюють, пояснюють зміст одного із членів головної предикативної частини, як-от: пояснюють зміст підмета: Коли хтось знизу помічав ї̈, то знову кричали - La Bella. Бо вона досі була нестримно, безтямно $i$ нестерпно гарною (Настя Байдаченко); деталізують зміст присудка: Спериу він иукав заспокоєння $i$ втихомирення в цееркві у квапливій безтолковій сповіді, та коли священик з амвону знову заводив про смертельні гріхи, Філіпп криво й уїдлво посміхався. Бо де ж тому святоші знати? (Настя Байдаченко); обгрунтовують зміст обставини: Час від часу дідугани згадували свою, таку миттєву, молодість, ту романтичну з порохом $i$ периими парубочими бійками юність, солодка вість поцілунку $i$ холодні туманні ранки на колгоспних полях. Бо ж обоє виростали $і$ нарощували свої м'язові тканини в епоху тракторів, гонитві за надреальними надоями молока, довгими чергами в продуктових магазинах (С. Грицюк);

2) поширюють основне висловлення, розкриваючи причину описуваного в базовій структурі: Тетяна ледь не задихнулася - з такою ясністю відчула, як иче треба співати. Адже пісня була про неі!! (Ірен Роздобудько); Якогось ранку прокинемося в іншій державі. Бо проспали свою (Л. Костенко); I коло ями близько не стійте. Бо то в горю можна упасти (М. Матіос).

Складнопідрядні речення з підрядним компонентом причини, у яких парцельоване підрядне речення за своїм змістом відповідає смисловому навантаженню всієї головної частини, становлять більшість 3-поміж 
опрацьованих ілюстрацій, ужитих у проаналізованих творах.

Спостереження показали: парцеляція - багатофункціональне синтаксичне явище. Результати опрацювання дібраного фактичного матеріалу дають змогу стверджувати, що в українській художній прозі, створеній наприкінці XX - початку XXI століття, парцельовані складнопідрядні речення 3 підрядним компонентом причини виконують такі функції (наводимо своє узагальнення функцій, виділених у праці О. С. Звєревої [5, с. 16-20]):

- конструктивну: поділ висловлювання на інтонаційно-смислові відрізки відповідно до композиційного задуму автора: [- ... Ви щзо, ті долари в роті пронесли? -] охолоджує всіх одна зі співрозмовницьь. Адже в палаті завжди має бути хтось скептично налаштований (Ірен Роздобудько);

- описову: висловлювання набуває смислової завершеності лише за умови сукупного сприйняття базової частини й парцелята: Маргарита ніколи не просила його влаштувати долю своїх байстрюків. Бо вона напевно хотіла для них звичної долі: цзерковної кар 'єри (Настя Байдаченко);

- смислотвірну: поглиблення змісту базової структури, розміщення значущої інформації в парцеляті: I будучою силою своєї любови він перемагає руйнуючу силу хамової злоби. Бо Хам шанує тільки силу (І. Корсак);

- емотивну: вияв емоцій мовця щодо навколишнього (- Йди собi геть. Бо як побачу щуе раз біля моєї крамниці, то начувайся (Настя Байдаченко) або емоційне оцінювання виниклої ситуації чи сказаного (- То хіба в духовному розвитку ви піднялися вище тхора, який душить курей? Адже тхір, залазячи в курник, теж вважає його сферою свойх інтересів (В. Даниленко);

- логічну: виявлення окремих законів логіки, зокрема закону достатнього причинового обгрунтування: Отож риби в потоках $і$ ріках тод $i$ прибувало, а людей мениало. Бо майже ніколи не є навпаки (М. Матіос).

Виконуючи окреслені функції, парцельовані складнопідрядні речення з підрядним компонентом причини виявляють значний комунікативний i стилістичний потенціал.

Так, уводячи розглядувані речення в мовлення персонажів автори надають їхнім реплікам особливого емоційного забарвлення, підкреслюючи мовленнєву експресію, яку мовці вкладають у своє висловлення: [Ліда стала біля ікони Божої Матері:] - Кайся, нянько. Бо така грішна... (Люко Дашвар), чи підкреслюють значущість інформації, наведеної в парцеляті, як-от: - Починайте відправу, отче. I якщц можна, то не розтягуйте. Бо нас тут і ранок застане (В. Шкляр).

Подаючи розлогі авторські описи, письменники характеризують емоційнопсихічний стан персонажа, підкреслюючи за допомогою парцелята напруженість і значущість описуваного: [Люди не люблять тужити. Вони взагалі нічого не люблять.] А Даруся не хоче не тужити за татом. Бо для неї тут не туга - тут, коло тата, лиш стільки їі справжснього жсиття (М. Матіос), або доходять філософських узагальнень, основне смислове () О. О. Волобуєва, 2013. 
навантаження яких містить парцельоване підрядне речення 3 підрядним компонентом причини, як-от: [Люди в селі не знали й щзо думати.] Бачили, як шуиро молиться їх наставник $і$ катує себе постом, а від того стали щуе більше поважати і навіть боятися його. Бо віра, щцра і правдива, сильна вона дає людині небачену міць і здатність творити дива (С. Грицюк), або, уводячи цитати 3 прецедентних текстів, створюють смисловий контраст між змістом частин парцельованого речення і цим актуалізує зміст парцелята: [Проте, як би там не поверталися думки в мізках лондонських чи паризьких політиків, має здійснитися писане у «Законі Божсому»:] «Лежсить в могилі Украӥна, але не вмерла... Бо голос України не затих» (І. Корсак).

Проаналізовані складнопідрядні речення 3 парцельованим підрядним компонентом причини виступають у творах сучасних українських прозаїків як повноправні комунікативні варіанти непарцельованих синтаксичних одиниць відповідної семантики.

Парцельовані складнопідрядні речення 3 підрядним компонентом причини реалізуються як синтаксичні одиниці, що мають значний комунікативний і стилістичний потенціал, використовуються як засоби актуалізації змісту парцелята зі значенням причини, створення смислового контрасту у змісті базової структури й парцелята, мовленнєвої експресії і виконують конструктивну, описову, смислотвірну, емотивну й логічну функції в художніх текстах, які характеризуються різними жанрово-стильовими ознаками. Уживання розглядуваних синтаксичних конструкцій пояснюється прагненням митців створити динамічну художню оповідь, викликати напругу почуттів читача, активізувати його мислення, загострити увагу на зображуваному й підтримувати зацікавленість твором. Продовження розпочатого дослідження вбачаємо в дослідженні парцельованих складнопідрядних речень 3 підрядним компонентом причини з погляду прагматичної лінгвістики.

\section{Література}

1. Авласевич М. А. О парцелляции в современном русском литературном языке (на материале публицистики и художественных текстов) / М. А. Авласевич // Вестник Белорусского университета. Серия 4. Филология. - 1973. - №1. - С. 52-58.

2. Валгина Н. С. Синтаксис современного русского языка / Н. С. Валгина. - М. : Высшая школа, 1973. - 528 с.

3. Ванников Ю. В. Высказывания с парцелляцией сложного предложения / Ю. В. Ванников // Синтаксис речи и синтаксические особенности речи. - М. : Наука, 1979. - С. 261-264.

4. Жданович Л. М. Парцелляция в сложных причинных конструкциях Л. М. Жданович // Вопросы синтаксиса русского языка высшей и средней школы. Тюмень, 1975. - С. 11-23.

5. Звєрева О.С. Функціонування парцельованих конструкцій в сучасному російському поетичному мовленні (у порівнянні з українським) : автореферат дис. ... канд. філол. наук : 10.02.01 / Звєрева Олена Станіславівна. - К., 1998. - 22 с. 
6. Зелепукин Р. О. Парцелляция в художественной прозе В. Токаревой : структура, семантика, текстообразующие функции [Электронный ресурс] : дис. ... канд. филол. наук : 10.02.01 / Зелепукин Роман Олегович. - M., 2007. http://cheloveknauka.com/partsellyatsiya-v-hudozhestvennoy-proze-v-tokarevoy-strukturasemantika-tekstoobrazuyuschie-funktsii

7. Конопленко Н. А. Текстотвірний потенціал парцельованих конструкцій : дис. ... канд. філол. наук : 10.02.01 / Конопленко Наталія Анатоліївна. - Донецьк, 2007. - 186 с.

8. Конюхова Л. І. Явище парцеляції у мові сучасних засобів масової комунікації : дис. ... канд. філол. наук : 10.02.01 / Конюхова Любов Іванівна. - Львів, 1999. - 174 с.

9. Марич С. М. Структурні і смислові особливості парцельованих речень / С. М. Марич // Українське мовознавство. - Вип. 15. - К., 1998. - С. 75-78.

10. Орєхов В. В. Функціонально-комунікативні вияви парцельованих i приєднувальних конструкцій прислівного типу / В. В. Орєхов // Лінгвістика. - 2009. №1 (16). - С. 229-236.

11. Рыбакова Г.Н. О парцелляции временных и условных конструкций / Г.Н. Рыбакова // Вопросы синтаксиса русского языка. - Ростов н/Д : Изд-во Ростовского-на-Дону государственного университета, 1971. - С. 166-172.

12. Рычкова И. А. О текстообразующих функциях парцелляции в сложном синтаксическом целом / И. А. Рычкова // Грамматическая семантика русского языка. - Вологда, 1983. - С. 98-103.

13. Старовойт Ю. Л. Абзацна парцеляція речень у системі експресивного синтаксису : автореф. дис. ... канд. філол. наук : 10.02.01 / Старовойт Юрій Леонідович. - К., 1993. - 20 с.

14. Ступакова Л. И. О характере связи между частями парцеллированной конструкции / Л. И. Ступакова // Иностранные языки в школе. - 1972. - №3. - С. 99-101.

15. Суровенкова Л. С. Семантико-синтаксические особенности парцеллированных и присоединительных конструкций / Л. С. Суровенкова // Вопросы синтаксиса сложного предложения. - Иркутск : МГПИИЯ им. М. Тореза, 1981. - С. 89-99.

16. Шевченко Т. В. Парцеляція в сучасному поетичному мовленні другої половини XX століття : дис. ... канд. філол. наук : 10.02.01 / Шевченко Тетяна Василівна. - Дніпропетровськ, 2007. - 194 с.

17. Шитов В. А. Придаточные конструкции в роли самостоятельных синтаксических единиц / В. А. Шитов // Русский язык в школе. - 1968. - №3. - С. 91-93. 